\title{
Bioactive Compounds and Antioxidant Properties of Some Wild Plants with Potential Culinary Uses
}

\author{
GABRIELA LUTA, EVELINA GHERGHINA, DANIELA BALAN*, FLORENTINA ISRAEL-ROMING \\ University of Agronomical Sciences and Veterinary Medicine, Faculty of Biotechnologies, 59 Marasti Blvd., \\ 011464, Bucharest, Romania
}

\begin{abstract}
Since ancient times, wild plants have widely been traditionally consumed by different communities but today are gaining relevance due to their healthy properties. Vegetables, including wild edible species, constitute an important source of active natural products: micronutrients, especially vitamins and minerals and phytochemical compounds with antioxidant properties important in the prevention of various pathologies including degenerative, cardiovascular and neurological diseases. Some species of wild and cultivated edible plants were comparatively evaluated considering the content in bioactive compounds and the antioxidant capacity. Biochemical analysis of the fresh leaves indicated similar or even higher values of nutritive compounds (sugars, protids) and antioxidants (polyphenols, carotenoids, flavones, chlorophylls, ascorbic acid) in the species from spontaneous flora as dandelion (Taraxacum officinale), lesser celandine (Ficaria verna), wild garlic (Allium ursinum) than in the green lettuce and garden rocket commonly consumed around the world. Therefore, these wild plants could be recommended for consumers not only as new ingredients to improve their diet diversity but also for providing potential health benefits.
\end{abstract}

Keywords: antioxidants, garden rocket, green lettuce, nutritive compounds, wild plants

Wild edible plants, an important source for nutrition in many parts of the world, are the plants that have not been cultivated or domesticated, but are available from their natural habitat and are used as food or medicinal herbs. Often they have an important contribution to the diet, mainly in the rural populations. In particular, the use of wild edible plants in Europe has been especially related to periods of famine, when they are consumed as life-saving food [1]. Consumers appreciate wild edible plants mainly because of the taste and aroma, but its nutritional value is sometimes higher than several known common vegetables and fruits [2]. Moreover, numerous studies showed that wild species are rich in secondary metabolites with antioxidant and healthy properties providing protection against a number of chronic and degenerative diseases [3].

In the present research work some species of wild edible plants were evaluated for their potential in human nutrition considering the content in bioactive compounds and the antioxidant capacity: dandelion (Taraxacum officinale), lesser celandine (Ficaria verna syn. Ranunculus ficaria), wild garlic (Allium ursinum).

Dandelion leaves are considered to be very nutritious and can be eaten as a salad or fresh vegetable. In Asian cooking, for example, dandelion leaves are used like lettuce, boiled, made into soup or fried [4]. Traditionally Taraxacum officinale has been used as a remedy for jaundice and other disorders of the liver and gallbladder [5,6] and as a remedy for kidney disease, dyspepsia, heartburn, spleen, hepatitis and anorexia [7,8].

From lesser celandine the first leaves in spring are consumed as an excellent salad and also it can be used like spinach [9]. As medicinal herb their use for thousands of years in the treatment of haemorrhoids and ulcers has been reported [10].

Wild garlic have been reported for culinary use as a flavoring vegetable in various types of food due their flavor, aroma and taste [11, 12]. In Russia it is quite commonly added to soups, in Germany to salads and it can also be used as a spice in addition to fillings or sauces [13,14]. The traditional medicine uses the wild garlic as an antihypertensive, antiatherosclerotic, antimicrobial, antidiarrhoeal and antiphlogistic agents [12].

In parallel, cultivated plants as green lettuce (Lactuca sativa) and garden rocket (Eruca sativa) were also analyzed with the aim to achieving a comparative study of the species from spontaneous and cultivated flora.

Lettuce (Lactuca sativa) is one of the most widely consumed vegetables worldwide, low in calories, fat and sodium. It is a good source of fiber, iron, folate, vitamin $\mathrm{C}$ and various other health-beneficial bioactive compounds. Thus, different studies reported anti-inflammatory, cholesterol-lowering, and anti-diabetic activities attributed to the bioactive compounds in lettuce $[15,16]$.

Garden rocket (arugula) (Eruca sativa) is one of the nutritious green leafy vegetables of Mediterranean origin, with a distinctive flavor, a pungent taste and numerous beneficial compounds, providing high antioxidant activity (vitamin C, carotenoids, chlorophylls, phenolics) [17,18]. In addition to food intake, rocket was traditionally known for its

*email: balan.dana@gmail.com 
medicinal properties. It was used to treat eye infections, act as a deodorant, and a digestive. It was also used as a diuretic, stimulant and a laxative, attributable to the presence of vitamin $C$ and mineral salts [19].

Biochemical determinations of the content in nutritive compounds (sugars, protids) and antioxidants (polyphenols, carotenoids, flavones, chlorophylls, ascorbic acid) as well as antioxidant activity were performed in the fresh leaves. Thus, the study was designed to acquire knowledge concerning the potential of wild edible plants to provide essential nutrients, which can improve well-being and quality of life.

\section{Experimental part}

Materials and methods

Three species of wild edible plants consumed in the traditional Romanian diet were evaluated: dandelion (Taraxacum officinale), lesser celandine (Ficaria verna syn. Ranunculus ficaria), wild garlic (Allium ursinum). For each sample several plants were used and all were collected from the spontaneous flora of Romania. Furthermore species of green lettuce and garden rocket commonly consumed as salads around the world were also analyzed in order to performe a comparative study.

\section{Biochemical analysis methods}

Biochemical compounds and the antioxidant capacity were determined using appropriate analysis methods. The determinations were made in triplicate, using fresh leaves. The extractions were conducted according to the protocol used for each determination.

Determination of total soluble sugars was performed according to the Somogyi-Nelson method [20,21]. Non-reducing sugars were first transformed in reducing sugars by hydrolysis with hydrochloric acid. The reducing sugars heated with alkaline copper tartrate reduce the copper and cuprous oxide is formed. Addition of arsenomolybdic acid led to reduction of molybdic acid to molybdenum blue. The measurements of absorbance were achieved at $620 \mathrm{~nm}$ with a UV/Visible ThermoSpectronic Helios spectrophotometer. The results were expressed in $\mathrm{g} \%$ fresh weight.

Determination of crude protein was made after the digestion of the vegetal material by Kjeldahl method [20,22]. The content in total nitrogen was measured by volumetrical method and converted in crude protein content. The results were expressed in $\mathrm{g} \%$ fresh weight.

Total phenolic content was performed according to the modified Folin-Ciocalteu assay [23]. The method consists in chemical reduction of Folin-Ciocalteu reagent and measuring the intensity of the obtained blue colour at $750 \mathrm{~nm}$. The measurements were achieved with a UV/Visible ThermoSpectronic Helios spectrophotometer. Total phenolic values were expressed in terms of gallic acid equivalents (mg GAE/g fresh weight).

Flavonoid content was determined using a colorimetric method based on the reaction with aluminium chloride [24]. The absorbance of the reaction mixture was measured at $420 \mathrm{~nm}$. Total flavonoids content were calculated using a calibration curve and were expressed as quercetin equivalents.

Ascorbic acid content was estimated by colorimetric method with a dye solution of 2,6-dichlorophenol indophenol [25]. Extraction of ascorbic acid was made in $2 \%$ oxalic acid. Absorbance was measured at $500 \mathrm{~nm}$ with UV-VIS Thermo Spectronic Helios spectrophotometer. Results were expressed as mg /100 g fresh weight.

Determinations of the assimilatory pigments content was made after chlorophyll and carotenoid pigments extraction in $80 \%$ acetone and spectrophotometrically measured at $663 \mathrm{~nm}, 647 \mathrm{~nm}$ and $480 \mathrm{~nm}$. The extinction coefficients and equations described by Schopfer (1989) were used for calculation [26]. The results were expressed in $\mathrm{mg} / 100 \mathrm{~g}$ fresh weight.

Dry matter content was analyzed by gravimetric method: samples had been dried to constant mass in a Venticell oven at $(105 \pm 5){ }^{\circ} \mathrm{C}$ and the loss of weight is used to calculate the dry matter content of the sample.

Total antioxidant capacity (radical scavenging activity) was determined using the stable free radical diphenylpicrylhydrazyl (DPPH) method according to Blois (1958) procedure adaptated by Brand-Williams et al. (1995) for complex matrices [27,28]. Briefly, a $100 \mu \mathrm{M}$ solution of DPPH in methanol was prepared and $2 \mathrm{ml}$ of this solution was mixed with $1 \mathrm{ml}$ of different concentrations leaves in $80 \%$ aqueous methanol. After 30 min incubation in dark at room temperature, absorbance (A) was measured at $515 \mathrm{~nm}$. The percentage of the radical scavenging activity (RSA) was calculated as follows:

$$
\% \operatorname{RSA}=\left(1-\left[\mathrm{A}_{\text {sample }} / \mathrm{A}_{\text {control } \mathrm{t}=0}\right]\right) / 100
$$


DPPH solution in $80 \%$ methanol was used as a control. The $\mathrm{EC}_{50}$ parameter for each sample, defined as the concentration of sample which is required to scavenge 50\% of DPPH free radicals, was calculated from the linear regression curve of the sample extracts $(\mathrm{mg} / \mathrm{ml})$ against the percentage of the radical scavenging activity.

Statistical analyses were performed with the one-way Analysis of Variance (ANOVA). All measurements were carried out in triplicate, and the results are presented as means \pm S.D. The relationship between the $\mathrm{EC}_{50}$ values and some antioxidant compounds (vitamin C, phenolics, flavonoids, chlorophylls, carotenoids) contents was performed via Pearson's correlation coefficient $(R)$ and determining coefficient $\left(R^{2}\right)$. A significant difference was considered at the level of $\mathrm{P}<0.05$.

\section{Results and discussions}

Analysis of nutritive compounds

The results obtained in the present study regarding the nutritive compounds (Table 1) in the analysed species showed that wild species registered similar or even higher values of the biochemical parameters compare to cultivated species.

Thus, close values of dry matter content were noted (between 10.73 in wild garlic and $13.49 \mathrm{~g} \%$ in dandelion leaves), except for green lettuce, which registered only $5.93 \mathrm{~g} \%$. However, total soluble sugars content was higher in the lettuce leaves $(1.52 \mathrm{~g} \% \mathrm{FW})$ compare to rocket leaves $(0.81 \mathrm{~g} \% \mathrm{FW})$. Remarkable from this point of view is lesser celandine, which registered the high amount of sugars $(3.71 \mathrm{~g} \% \mathrm{FW})$. Great amount of crude protein were determined in the leaves of wild garlic (4.03 $\mathrm{g} \% \mathrm{FW})$ and dandelion $(3.82 \mathrm{~g} \% \mathrm{FW})$ among the wild species, while rocket registered the highest value $(4.07 \mathrm{~g} \% \mathrm{FW})$.

Green lettuce leaves were found with low accumulation of crude protein $(1.42 \mathrm{~g} \% \mathrm{FW})$ in according with previous studies which reported similar values and showed that protein concentrations in green lettuce leaves were affected by growing season (13.2-16.5 mg/g FW in spring season and 10.2-15.2 mg/g FW in summer season) [29].

Table 1

ACCUMULATION OF NUTRITIVE COMPOUNDS IN THE TESTED LEAVES

\begin{tabular}{|c|c|c|c|}
\hline Samples & $\begin{array}{c}\text { Dry weight } \\
(\mathrm{g} \%)\end{array}$ & $\begin{array}{c}\text { Total soluble sugars (g\% } \\
\text { FW) }\end{array}$ & $\begin{array}{c}\text { Crude protein } \\
(\mathrm{g} \% \text { FW) }\end{array}$ \\
\hline Green lettuce & $5.93 \pm 0.38^{\mathrm{a}}$ & $1.52 \pm 0.10^{\mathrm{b}}$ & $1.42 \pm 0.13^{\mathrm{a}}$ \\
\hline Garden rocket & $11.80 \pm 0.35^{\mathrm{c}}$ & $0.81 \pm 0.06^{\mathrm{a}}$ & $4.07 \pm 0.18^{\mathrm{d}}$ \\
\hline Wild garlic & $10.73 \pm 0.25^{\mathrm{b}}$ & $1.34 \pm 0.12^{\mathrm{b}}$ & $4.03 \pm 0.05^{\mathrm{d}}$ \\
\hline Lesser celandine & $12.35 \pm 0.47^{\mathrm{c}}$ & $3.71 \pm 0.16^{\mathrm{c}}$ & $2.14 \pm 0.12^{\mathrm{b}}$ \\
\hline Dandelion & $13.49 \pm 0.22^{\mathrm{a}}$ & $0.98 \pm 0.10^{\mathrm{a}}$ & $3.82 \pm 0.08^{\mathrm{c}}$ \\
\hline
\end{tabular}

Note: Data expressed as means \pm standard deviation of three samples analyzed separately; different superscript letters within the same column indicate significant differences $(\mathrm{P}<0.05)$.

\section{Analysis of antioxidant compounds}

The lowest amount of vitamin $C$ was recorded in the lettuce leaves (13.49 mg/100 g FW) (Table 2), corresponding to the data reported by Aćamović-Djoković et al. (2011), which found different values of vitamin C content in some lettuce varieties $(9.60 \mathrm{mg} / 100 \mathrm{~g} \mathrm{FW}$ for Levistro, but only $3.50 \mathrm{mg} / 100 \mathrm{~g} \mathrm{FW}$ in the Murai variety) [30]. The analysed wild species accumulated higher values of vitamin $\mathrm{C}$ compare to the lettuce, between $23.08 \mathrm{mg} / 100 \mathrm{~g} \mathrm{FW}$ in the dandelion leaves and $93.84 \mathrm{mg} / 100 \mathrm{~g} \mathrm{FW}$ in the lesser celandine leaves. Aslo, previous studies reported important amounts of vitamin $C$ in different wild edible species: $121.86 \mathrm{mg} / \mathrm{kg}$ in dandelion leaves [6] and $75.4-459.7 \mathrm{mg} / \mathrm{kg}$ in wild garlic of polish origin [31].

Garden rocket instead was found with the highest content in vitamin C $(147.86 \mathrm{mg} / 100 \mathrm{~g} \mathrm{FW})$, while the cited literature mentions a great variation on the reported values: from $15 \mathrm{mg} / 100 \mathrm{~g} \mathrm{FW}$ [32] to $68-80 \mathrm{mg} / 100 \mathrm{~g} \mathrm{FW}$ [33] and $128 \mathrm{mg} / 100 \mathrm{~g} \mathrm{FW} \mathrm{[34]} \mathrm{vitamin} \mathrm{C} \mathrm{in} \mathrm{the} \mathrm{rocket} \mathrm{leaves.}$

Table 2

ACCUMULATION OF SOME ANTIOXIDANT COMPOUNDS IN THE TESTED LEAVES

\begin{tabular}{|c|c|c|c|}
\hline Samples & $\begin{array}{c}\text { Vitamin C } \\
(\mathrm{mg} / 100 \mathrm{~g} \mathrm{FW})\end{array}$ & $\begin{array}{c}\text { Total phenolics } \\
(\mathrm{mg} \mathrm{GAE} / 100 \mathrm{~g} \mathrm{FW})\end{array}$ & $\begin{array}{c}\text { Total flavonoids } \\
(\mathrm{mg} / 100 \mathrm{~g} \mathrm{FW})\end{array}$ \\
\hline Green lettuce & $13.49 \pm 1.13^{\mathrm{a}}$ & $55.36 \pm 3.96^{\mathrm{a}}$ & $35.31 \pm 1.55^{\mathrm{a}}$ \\
\hline Garden rocket & $147.86 \pm 12.10^{\mathrm{c}}$ & $254.41 \pm 13.29^{\mathrm{c}}$ & $102.38 \pm 6.85^{\mathrm{c}}$ \\
\hline Wild garlic & $79.84 \pm 2.76^{\mathrm{c}}$ & $242.04 \pm 10.46^{\mathrm{c}}$ & $176.40 \pm 8.85^{\mathrm{d}}$ \\
\hline Lesser celandine & $93.84 \pm 2.66^{\mathrm{d}}$ & $275.74 \pm 21.39^{\mathrm{c}}$ & $200.94 \pm 10.06^{\mathrm{c}}$ \\
\hline Dandelion & $23.08 \pm 1.35^{\mathrm{b}}$ & $104.06 \pm 10.00^{\mathrm{b}}$ & $77.85 \pm 5.05^{\mathrm{b}}$ \\
\hline
\end{tabular}

Note: Data expressed as means \pm standard deviation of three samples analyzed separately; different superscript letters within the same column indicate significant differences $(\mathrm{P}<0.05)$. 
Total phenolics contents determined in the analysed species (Table 2) reached high values in the garden rocket (254.41 mg GAE/100 g FW), in according with the amount (208.11 mg GAE/100g FW) detected by Heimler et al. (2007) [35]. Also the values determined in the leaves of lesser celandine (275.74 mg GAE/100 g FW) and wild garlic (242.04 mg GAE/100 g FW) was high, highlighting the antioxidant potential of these wild species. Numerous researches anterior performed reported that wild edible herbs are rich in antioxidant compounds as polyphenols. Thus, total polyphenol content in wild garlic leaves and flowers during the vegetation period from the area of Bratislava ranged from $726 \pm 10 \mathrm{mg} \mathrm{GAE} / \mathrm{kg} \mathrm{FW}$ to $1410 \pm 13 \mathrm{mg} \mathrm{GAE} / \mathrm{kg} \mathrm{FW}$ [36], while in wild garlic of polish origin polyphenols reached $335.3-1895.1 \mathrm{mg} / \mathrm{kg}$ [32].

Green lettuce instead accumulated the lowest amount of total phenolics (55.36 mg GAE/100 g FW) as other authors have pointed out. For example, Llorach et al. (2008) determined values between 18.2-125.5 mg/100 g FW polyphenols studying several varieties of lettuce [37].

Also total flavonoids amount determined in green lettuce was the lowest among the analyzed species (35.31 $\mathrm{mg} / 100 \mathrm{~g} \mathrm{FW}$ ), while some wild herbs reached high values such as $200.94 \mathrm{mg} / 100 \mathrm{~g}$ FW in lesser celandine and 176.4 $\mathrm{mg} / 100 \mathrm{~g}$ FW in wild garlic (Table 2).

Content in assimilatory pigments, meaning total chlorophylls and total carotenoids of the herbal species was analyzed too (Table 3). The antioxidant potential of carotenoids and its role in preventing some cancer are known, but also for chlorophyll new nutritional roles, including anti-cancer activity, are being investigated [15].

Table 3

ACCUMULATION OF ASSIMILATORY PIGMENTS IN THE ANALYZED SPECIES

\begin{tabular}{|c|c|c|}
\hline Samples & $\begin{array}{c}\text { Total chlorophylls } \\
(\mathrm{mg} / 100 \mathrm{~g} \mathrm{FW})\end{array}$ & $\begin{array}{c}\text { Total carotenoids } \\
(\mathrm{mg} / 100 \mathrm{~g} \mathrm{FW})\end{array}$ \\
\hline Green lettuce & $82.64 \pm 4.52^{\mathrm{a}}$ & $3.36 \pm 0.06^{\mathrm{a}}$ \\
\hline Rocket & $137.32 \pm 12.65^{\mathrm{b}}$ & $3.86 \pm 0.07^{\mathrm{b}}$ \\
\hline Wild garlic & $174.49 \pm 17.09^{\mathrm{c}}$ & $5.29 \pm 0.41^{\mathrm{c}}$ \\
\hline Lesser celandine & $186.82 \pm 10.31^{\mathrm{c}}$ & $6.92 \pm 0.09^{\mathrm{d}}$ \\
\hline Dandelion & $247.19 \pm 4.65^{\mathrm{d}}$ & $5.61 \pm 0.29^{\mathrm{c}}$ \\
\hline
\end{tabular}

Note: Data expressed as means $=$ standard deviation of three samples analyzed separately; different superscript letters within the same column indicate significant differences $(P<0.05)$.

Analysis of assimilatory pigments content revealed that wild species reached high values compare to the values recorded by the cultivated salad species (Table 3). Thus, dandelion accumulated the most chlorophyll ( $247.19 \mathrm{mg} / 100$ g FW) and a high amount of carotene (5.61 mg/100 g FW) similar to the values reported by Znidarcic et al. (2011) $(248.25 \pm 38.26 \mathrm{mg} / 100 \mathrm{~g}$ FW total chlorophyll and $6.34 \mathrm{mg} / 100 \mathrm{~g}$ FW carotene) [38].

Total antioxidant capacity (radical scavenging activity) of extracts from all analyzed herbal species was evaluated and the $\mathrm{EC}_{50}$ values for every tested plant were calculated for further comparison. The measurements indicated the highest antioxidant activity for lesser celandine $\left(14.22 \mathrm{mg} / \mathrm{mL}\right.$ expressed as $\mathrm{EC}_{50}$ value), confirming the expectations due to their rich content in total phenolics (Table 4). These results are in according to those obtained by Barla et al. (2014), which noted that generally high levels of phenolic compounds are responsible for strong antioxidant capacity [39]. The lowest scavenging capacity was noted in the leaves of green lettuce, which required a higher concentration $(62.34 \mathrm{mg} / \mathrm{mL})$ to scavenge $50 \%$ of DPPH free radicals.

Table 4

EC $_{50}$ VALUES OF DPPH SCAVENGING ACTIVITIES OF THE TESTED LEAVES

\begin{tabular}{|c|c|}
\hline Samples & EC $_{50}(\mathrm{mg} / \mathrm{mL})$ \\
\hline Green lettuce & $62.34 \pm 2.89^{\mathrm{c}}$ \\
\hline Rocket & $25.28 \pm 2.44^{\mathrm{b}}$ \\
\hline Wild garlic & $17.39 \pm 1.46^{\mathrm{a}}$ \\
\hline Lesser celandine & $14.22 \pm 1.68^{\mathrm{a}}$ \\
\hline Dandelion & $25.42 \pm 3.08^{\mathrm{b}}$ \\
\hline Note: Data expressed as means \pm standard deviation of three \\
samples analyzed separately; different superscript letters within the \\
same column indicate significant differences $(\mathrm{P}<0.05)$.
\end{tabular}


Also a correlation study was performed in the present paper between the radical scavenging activity (expressed as $\mathrm{EC}_{50}$ ) and the content in antioxidants in order to reveal the contribution of these biochemical compounds to the total antioxidant capacity of the herbal species analyzed (Figure 1).

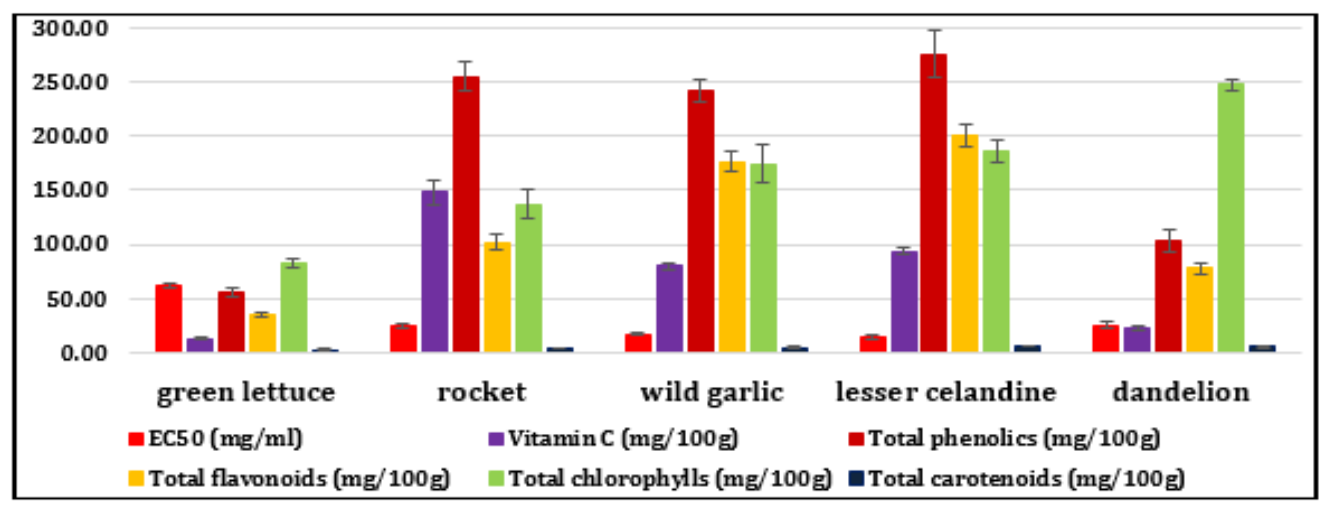

Fig. 1. Content of phytochemical constituents and radical scavenging activity

Using Pearson's correlation coefficient, which quantifies the linear association between two quantitative variables, it was possible to estimate the relationships between the different antioxidant activities of the extracts and their contents of phytochemical constituents. Total phytochemical constituents analyzed have a very strong negative correlation with the $\mathrm{EC}_{50}$ values in leaves extract $(\mathrm{R}=-0.9291, \mathrm{p}<0.05)$. Among them the strongest negative correlation was exhibit by flavonoids $(\mathrm{R}=-0.8321, \mathrm{p}<0.05)$, indicating that these phytochemicals are the major contributors of antioxidant capacity between present phenolics. The results revealed excellent correlations between the antioxidant activities of the different extracts and their contents of polyphenols. Strong correlations were found also for chlorophylls and carotenoids. A moderate correlation was observed between the antioxidant activities and the vitamin $\mathrm{C}$ contents, which demonstrated that the presence of a considerable amount of these compounds in a plant does not always imply a corresponding antioxidant potential. Correlation coefficients between different constituents evaluated and $\mathrm{EC}_{50}$ values are given in Table 5.

Table 5

STATISTICAL DEPENDENCE BETWEEN PHYTOCHEMICAL CONSTITUENTS AND ANTIOXIDANT ACTIVITY (EC $\left.5_{0}\right)$ OF EXTRACT LEAVES

\begin{tabular}{|c|c|c|}
\hline Phytochemical constituents & $\begin{array}{c}\text { R (coefficient } \\
\text { of correlation) }\end{array}$ & $\mathbf{R}^{2}$ (determining coefficient) \\
\hline Vitamin C & -0.5763 & 0.3321 \\
\hline Total phenolics & -0.8117 & 0.9009 \\
\hline Total flavonoids & -0.8321 & 0.9122 \\
\hline Total chlorophylls & -0.7053 & 0.8398 \\
\hline Total carotenoids & -0.7507 & 0.8664 \\
\hline Total phytochemical constituents & -0.9291 & 0.9639 \\
\hline
\end{tabular}

\section{Conclusions}

Although modern food is usually poor in vegetables, an increased consumption of the antioxidant-rich plants, both cultivated and wild species, could provide health benefits.

The results obtained in present study regarding the nutritive compounds in the investigated species showed that wild edible species (wild garlic, dandelion, lesser celandine) registered similar or even higher values of the biochemical parameters compare to cultivated species of salads (garden rocket and green lettuce).

Also an outstanding antioxidants content, therefore a high radical scavenging capacity, was determined in the wild edible species. Thus, lesser celandine was found with the highest values of vitamin $\mathrm{C}$ and total phenolics, flavonoids, carotenoids and chlorophylls, but close values were also determined in wild garlic and dandelion. However, caution is advised regarding the use of lesser celandine for food because the leaves turn poisonous as the fruit matures [40]. Cooking of the leaves eliminates its toxicity and the plant has been incorporated in diets or herbal medicine after being dried or boiled and consumed as a vegetable [40]

Among the cultivated salad species analyzed, the garden rocket was noted with a good nutritive and antioxidant compounds content.

In conclusion, the plants we have investigated seems attractive because of their high nutritive compounds content and high antioxidant activity. Since antioxidant activity and content in bioactive compounds is related with biological activities, this study emphasized the potential use of the investigated wild edible plants as functional food ingredient or nutraceutical. Therefore, these wild plants could be recommended for consumers not only as new ingredients to improve their diet diversity but also for providing potential health benefits. 


\section{References}

1. PETROPOUlOS, S., A., KARKANIS, A., MARTINS, N., FERREIRA, I., C., F., R., Trends Food Sci. Technol., 74, 2018 , p. 69.

2. ROMOJARO, A., ÁNGELES, BOTELlA, M., OBÓN, C., PRETEL, M., T., Int. J. of Food Sci. and Nutrition, 64, no. 8, 2013 , p. 944.

3. CECCANTI, C., LANDI, M., BENVENUTI, S., PARDOSSI, A., GUIDI, L., Molecules, 23, 2018, p. 2299.

4. TANAKA, Y., NGUYEN, V., K., Edible Wild Plants of Vietnam. The Bountiful Garden. Orchid Press. Bangkok, 2007, p. 175.

5. FAZILI, K., M., ALI, Y., HUSSAIN, S.,S., ANDRAB, A., WAFAI, B., A., Science and Technology, 3, no.10, 2011 , p. 118.

6. PADURET, S., AMARIEI, S., GUTT, G., PISCUC, B., Romanian Biotechnological Letters, 21, no. 3, 2016, p. 11569.

7. SWEENEY, B., VORA, M., ULBRICHT, C., BASCH, E., Journal of Herbal Pharmacotherapy, 5, 2005, p. 79.

8. SCHUTZ, K., CARLE, R., SCHIEBER, A., Journal of Ethnopharmacology, 107, 2006, p. 313.

9. TURNER, N., J., JAKUB, L., MIGLIORINI, P., PIERONI, A., DREON, A., L, SACCHETTI, L., E., PAOLETTI, M,. G., Critical Reviews in Plant Sciences, 30, 2006, p. 198.

10. ALLEN, D., E., HATFIELD, G., Medicinal Plants in Folk Tradition: An ethnobotany of Britain \& Ireland. Timber Press. Portland, Oregon, 2004, p. 215.

11. GORECKI, P., Herba Pol. 47, 2001, p. 85.

12. STAJNER, D., VARGA, I., S., An Acta Biologica Szegediensis 47, 2003, p. 103.

13. JANECZKO, Z., SOBOLEWSKA, D., Wiad. Zielarskie, 4, 1995, p. 12.

14. BŁAZEWICZ-WOZNIAK, M., MICHOWSKA, A., L. Acta Agrobot. 64, no. 4, 2011, p.171.

15. HEDGES, L. J., LISTER, C. E., Crop \& Food Research Report No. 1473, 2005.

16. KIM, M., J., MOON, Y., TOU, J., C., WATERLAND, N., L., Journal of Food Composition and Analysis, 49, 2016 , p. 19.

17. HALL, M., K., D., JOBLING, J., J., ROGERS, G., S., Veg. Crop Res. Bull. 76, 2012, p. 21.

18. VILlATORO-PUlidO, M., PRIEGO-CAPOTE, F., ÁlVAREZ-SÁNCHEZ, B., SAHA, S., PHILO, M., OBREGÓN-CANO, S., J. Sci. Food Agric. 93, 2013, p. 3809.

19. ALRUWAIH, N., Comparison of lyophilized and tray-dried rocket (E. sativa). Master degree Thesis, McGill University, Montreal, Quebec, 2016, p. 1.

20. IORDACHESCU, D., DUMITRU, I., F., Biochimie practica, Ed. Universitatea Bucuresti, Bucuresti, 1988, p. 115, p. 205.

21. SOMOGYI, M., Journal of Biological Chemistry, 195, no.1, 1952, p. 19.

22. KJELDAHL, J., Zeitschrift für analytische Chemie, 22, no.1, 1883, p. 366.

23. SINGLETON, V., L., ORTHOFER, R., LAMUELA-RAVENTOS, R., M., LESTER, P., Meth. Enzymol. 299, 1999 , p. 152.

24. NICKAVAR, B., KAMALINEJA, D., M., HAJ-YAHYA, M., SHAFAGHI, B., Pharm. Biol., 44, 2006, p. 208.

25. ARTENIE, V., TANASE, E., Practicum of general biochemistry, Ed. Al. I. Cuza University, Iasi, 1981, p. 279.

26. SCHOPFER, P., Experimentelle Pflanzenphysiologie. Springer-Verlag, Berlin, 1989, p. 33.

27. BLOIS, M., S., Nature, 181, 1958, p. 1199.

28. BRAND-WILLIAMS, W., CUVELIER, M., E., BERSET, C., Lebensmittel-Wissenschaft und Technologie/Food Science and Technology, 28, 1995, p. 25.

29. FALlOVO, C., ROUPHAEL, Y., REA, E., BATTISTELliD, A., COLlAA, G., J Sci Food Agric, 89, 2009, p. 1682.

30. AĆAMOVIĆ-DJOKOVIĆ, G., PAVLOVIĆ, R., MLADENOVIĆ, J., DJURIĆ M., Acta Agriculturae Serbica, 16, no. 32, 2011, p. 83.

31. PIĄTKOWSKA, E., KOPEĆ, A., LESZCZYŃSKA, T., Nauka. Technologia. Jakość, 1, no. 98, 2015, p. 181.

32. USDA, National nutrient database for standard reference. 2006.

33. KOUKOUNARAS, A., SIOMOS, A., S., SFAKIOTAKIS, E., Biol. Technol. 46, 2007, p. 167.

34. MARTINEZ-SANCHEZ, A., ALLENDE, A., BENNET, R., N, FERRES, F., GIL, M., I., Postharvest Biology and Technology 42, no. 1, 2006, p. 86.

35. HEIMLER, D., ROMANI, A., VIGNOLINI, P., ISOLANI, L., J. Agric. Food Chem. 55, 2007, p. 1724.

36. TÓTH, T., KOVAROVIČ, J., BYSTRICKÁ, J., VOLLMANNOVÁ, A., Acta Alimentaria, 47, no. 2, 2018, p. 252.

37. LLORACH, R., MARTÍNEZ-SÁNCHEZ, A., TOMÁS-BARBERÁN, F., A., GIL, M., I., FERRERES, F., Food Chemistry, 108, no. 3, 2008, p. 1028.

38. ZNIDARCIC, D., BAN, D., SIRCELJ, H., Food Chemistry, 129, no. 3, 2011, p. 1164.

39. BARLA, G.,F., POROCH-SERITAN, M., SANDULEAC, E., CIORNEI, S.,E., Journal of Faculty of Food Engineering Suceava, 13, no 4, 2014 , p. 349.

40. MITHEN, S., FINLAY, N., CARRUTHERS, W., CARTER ,S., ASHMORE, P., Scotland. J. Archaeol. Sci, 28, 2001 , p. 223.

Manuscript received: 22.05 .2019 